University of Nebraska - Lincoln

DigitalCommons@University of Nebraska - Lincoln

Sociology Department, Faculty Publications

Sociology, Department of

$1-2020$

\title{
State-Level Determinants of Hate Crime Reporting: Examining the Impact of Structural and Social Movement Influences
}

Heather L. Scheuerman

James Madison University, scheuehl@jmu.edu

Christie L. Parris

Oberlin College, Christie.Parris@oberlin.edu

Alison H. Faupel

US Department of State

Regina E. Werum

University of Nebraska-Lincoln, rwerum2@unl.edu

Follow this and additional works at: https://digitalcommons.unl.edu/sociologyfacpub

Part of the Family, Life Course, and Society Commons, and the Social Psychology and Interaction

Commons

Scheuerman, Heather L.; Parris, Christie L.; Faupel, Alison H.; and Werum, Regina E., "State-Level Determinants of Hate Crime Reporting: Examining the Impact of Structural and Social Movement Influences" (2020). Sociology Department, Faculty Publications. 713.

https://digitalcommons.unl.edu/sociologyfacpub/713

This Article is brought to you for free and open access by the Sociology, Department of at DigitalCommons@University of Nebraska - Lincoln. It has been accepted for inclusion in Sociology Department, Faculty Publications by an authorized administrator of DigitalCommons@University of Nebraska - Lincoln. 


\title{
State-Level Determinants of Hate Crime Reporting: Examining the Impact of Structural and Social Movement Influences
}

\author{
HEATHER L. SCHEUERMAN, CHRISTIE L. PARRIS, ALISON H. FAUPEL and \\ REGINA WERUM
}

\begin{abstract}
In this article, we investigate factors affecting hate crime policies by examining anti-LGBT (lesbian, gay, bisexual, transgender) hate crime reports as a type of policy implementation. Analyzing state-level data drawn primarily from the US Census between 1995 and 2008, we examine how structural and social movement mobilization factors explain hate crime reporting. We find that anti-LGBT hate crimes are more likely to be reported in more urbanized states and in states with both split political elites and a greater number of LGBT social movement organizations. We discuss the implications of our findings for separating the drivers of policy passage from policy implementation and for complementary criminological and social movement explanations for hate crime reporting.
\end{abstract}

\section{INTRODUCTION}

Social movement and sociolegal scholarship generally focuses on the passage of legislation as a measure of movement outcomes, examining how underlying structural conditions and the capacity of and choices made by social movements might explain differential policy success (Jenness and Grattet 1996; Boutcher, Kronberg, and Werum 2018). While this research has typically treated policy passage as the outcome of interest, social movements themselves often focus on how well those policies are implemented, recognizing that legal change is only half the battle (Andrews 2001; Coe 2012; Sturdy, Smith-Merry, and Freeman 2012; Gibson 2017). ${ }^{1}$

In this article, we examine the enforcement of hate crime policy as a case for exploring whether the same factors that drive policy passage also contribute to policy implementation (see Haider-Markel 1998). Hate crime enforcement is a complex process that requires law enforcement to detect, investigate, report, and prosecute crimes as hate crimes, providing multiple opportunities for the state to decline enforcement (Grattet and Jenness 2008). Anti-LGBT (lesbian, gay, bisexual, transgender) hate crimes in particular face a wide gap between their occurrence and the willingness of law enforcement to label those acts as hate crimes (Grattet and Jenness 2008; Stotzer 2010b; Herek 2017).

Address correspondence to: Heather L. Scheuerman, Department of Justice Studies, James Madison University, Moody Hall 213, MSC 1205, Harrisonburg, VA, 22807, USA; Telephone 540-568-4332; Email: scheuehl@jmu.edu. 
According to the 2015 National Crime Victimization Survey, approximately 22 percent of hate crimes were due to sexual orientation bias, resulting in an estimate of over 45,000 incidents (Masucci and Langton 2017). However, law enforcement agencies that participate in the Federal Bureau of Investigation's (FBI) Uniform Crime Reports (UCR) indicate that, nationally, only 1,263 hate crimes based on sexual orientation were reported in 2015 (UCR 2015). ${ }^{2}$ Thus, the passage of anti-LGBT hate crime legislation (Jenness and Grattet 2001; Parris and Scheuerman 2015; Herek 2017) does not necessarily translate into policy enforcement (Dwyer 1990; Grattet and Jenness 2008), providing a good case study for investigating the conditions under which ongoing social movement pressure leads to successful implementation of existing policy.

The hate crimes literature has pointed to two broad sources of hate crime occurrence. First, some criminologists have suggested that hate crime reporting is an outgrowth of underlying structural variables, such as social disorganization broadly defined (Grattet and Jenness 2008; Gladfelter, Lantz, and Rubak 2017). Specifically, the occurrence and reporting of hate crimes may increase due to structural inequality and social isolation, both of which tend to exacerbate tensions between various social groups (Grattet and Jenness 2008). A second body of research points to hate crime reporting as an outgrowth of activist organizations who pressure communities and law enforcement to label acts as hate crimes (McVeigh, Welch, and Bjarnason 2003; Grattet and Jenness 2008), suggesting that communities with stronger social movement organization (SMO) presence and resources will increase the rate of hate crime reporting (Grattet and Jenness 2008). In light of these complementary explanations, here we investigate to what extent state-level structural and social movement characteristics affect hate crime policy implementation.

We address this question by focusing on anti-LGBT hate crimes reported to the FBI in the United States between 1995 and 2008. In doing so, we extend the literature on hate crime enforcement in multiple ways. First, we examine whether SMO-related factors known to facilitate policy passage - that is, the strength of LGBT organizations and businesses (Werum and Winders 2001; Kane 2003; Soule 2004; Agnone 2007; Johnson 2008; Olzak and Soule 2009; Parris and Scheuerman 2015) — can be similarly applied to policy implementation (see also Haider-Markel 1998). Disentangling the mechanisms influencing policy passage and implementation can help differentiate symbolic policy gains from long-term policy impact (Amenta et al. 2010). Second, we extend extant research by providing a closer examination of the political consequences of social movements, including, but not limited to, the implementation of state policy (McVeigh, Welch, and Bjarnason 2003; Amenta et al. 2010; Barclay, Jones, and Marshall 2011; Boutcher 2011). Third, we examine the question of whether anti-LGBT hate crime reporting can best be explained by the types of structural conditions identified by criminologists or by the types of conditions identified by social movement scholars. Specifically, we ask whether the reporting of anti-LGBT hate crimes is higher in states that have structural conditions conducive to the occurrence of crimes or higher where LGBT organizations have a stronger presence and are formally included in the political process. Last, because we examine a specific type of bias crime and relevant factors affecting its reporting at the state level, this study is uniquely situated to identify how drivers of LGBT hate crime policy implementation compare to those applied to other studies of bias crimes at the community, city, or county level (e.g., McVeigh, Welch, and Bjarnason 2003; King 2007; Grattet and Jenness 2008; Holder 2018), which predominate in the literature on hate crimes.

Below, we first provide background on why anti-LGBT hate crimes provide an excellent case to study how state-level structural factors (see Grattet and Jenness 2008), movement resources, and the political context within which SMOs operate may explain 
the reporting of hate crimes. Then, we conduct time-sensitive fixed-effects negative binomial regressions to pinpoint how these variables may influence the reporting of antiLGBT hate crimes. We find that hate crime reporting is positively associated with urbanization and social movement organizational mobilization when political elites are split. We conclude by discussing the implications of our findings for understanding the mechanisms that shape the implementation of anti-LGBT hate crime statutes specifically, as well as those that shape policy implementation more generally.

\section{ANTI-LGBT HATE CRIMES}

Hate crimes, or bias crimes, are defined as "criminal offense[s] against a person or property motivated in whole or in part by an offender's bias against a race, religion, disability, sexual orientation, ethnicity, gender, or gender identity" (FBI 2019). Although LGBT hate crimes may be somewhat distinct from other forms of bias crimes, these crimes share many similarities with hate crimes in general (Briones-Robinson, Powers, and Socia 2016). Below, we first identify distinct aspects of anti-LGBT hate crimes. Then we discuss how an examination of these types of bias crimes can inform research on hate crime policy implementation.

There are a variety of reasons anti-LGBT hate crimes may be unique in comparison to other types of bias crimes. First, crimes perpetrated based on sexual orientation were not initially recognized in hate crime legislation, as the acknowledgment of sexual orientation as a protected status was more highly contested than the acknowledgment of race, religion, and ethnicity. While federal and state actors have passed legislation since the 1960s defining hate crimes and how they are enforced, sexual orientation was not incorporated into state hate crime legislation until the 1980s (Jenness and Grattet 2001; Herek 2017). LGBT social movement organizations specifically, and the gay liberation movement generally, played a central role in the passage of these policies at the federal and state level (Parris and Scheuerman 2015; Herek 2017). ${ }^{3}$

Federally, sexual orientation was recognized with the passage of the Hate Crime Statistics Act (HCSA), 28 U.S.C. $§ 534$ (1990), which mandated the collection of statistics on hate crimes. However, multiple attempts were made to pass the HCSA - with one version not including sexual orientation being passed by the House during the NinetyNinth Congress - and it was opposed initially by the Justice Department and by legislators in the House and Senate (see Haider-Markel 1998; Jenness and Grattet 2001). This opposition led special interest groups, such as the National Gay and Lesbian Task Force (NGLTF) and the American Psychological Association, to lobby to include sexual orientation in the HCSA (Herek 2017). Moreover, it was not until 2009, with the passage of the Matthew Shepard and James Byrd Jr. Hate Crimes Prevention Act, 18 U.S.C. $\S$ 249 (2009) that sexual orientation became a protected status at the national level (Haider-Markel 1998; Briones-Robinson, Powers, and Socia 2016; Herek 2017).

This contentious timeline leads us to focus on LGBT hate crimes reported to the FBI between 1995 and 2008. We begin with 1995, as this was the year that a substantial majority of the US population (75 percent) was covered by participating law enforcement agencies in the HCSA (Nolan, Akiyama, and Berhanu 2002). We end our focus in 2008, as this year captures LGBT hate crimes that occurred prior to the passing of the Matthew Shepard Act (see also Briones-Robinson, Powers, and Socia 2016) and, at the time of this writing, reflects the last year in which changes were made to state hate crime statutes recognizing sexual orientation as a protected status. ${ }^{4}$ 
Second, in addition to this history of political contention, there was a large degree of social turmoil surrounding LGBT issues. Several high-profile anti-LGBT hate crimes occurred, which brought national attention to violence perpetrated against the LGBT community. In 1988, Rebecca Wright and Claudia Brenner were attacked on the Appalachian Trail due to their sexual orientation, with Wright not surviving her gunshot wounds. In 1993, Brandon Teena was raped and murdered due to his sexual orientation and gender identity (Eaklor 2008). In 1998, Matthew Shepard died after being brutally victimized in Wyoming due to his sexual orientation. Since, at the time, this state did not have statutes that protected against bias-motivated acts, stronger efforts were made to improve protections at the national level (Briones-Robinson, Powers, and Socia 2016). LGBT hate crimes are thus uniquely suited to an examination of how state-level processes affect hate crime implementation, as states were the initial leaders in including sexual orientation in their hate crime legislation.

Third, victims of LGBT bias crimes may report their victimization less frequently than victims of other bias crimes due to fear of secondary victimization (Berrill and Herek 1990; Briones-Robinson, Powers, and Socia 2016). Unlike discrimination based on other protected statuses, discrimination based on sexual orientation was not recognized as a form of employment discrimination prior to 2015 (US Equal Employment Opportunity Commission 2018). As such, the reporting of antigay bias crimes could have resulted in workplace discrimination. Secondary victimization can also occur in the form of victims experiencing abuse from the police, public disclosure of sexual orientation, or being held responsible for their own victimhood (Berrill and Herek 1990; Briones-Robinson, Powers, and Socia 2016). Victims of anti-LGBT crimes may also be reluctant to report due to feelings of shame or embarrassment, especially due to the societal stigma sexual minorities face (Briones-Robinson, Powers, and Socia 2016; Herek 2017). Members of other protected classes do not have the added difficulty of "coming out" to the police when reporting their victimization (Briones-Robinson, Powers, and Socia 2016).

Finally, LGBT hate crimes tend to be more violent and to produce greater victim injury than other forms of bias victimization (Briones-Robinson, Powers, and Socia 2016). The severity of these crimes relates not only to the degree of physical injury but also to the degree of psychological injury. This form of crime is particularly salient for sexual minorities because such crimes violate victims' sense of self by attacking a key feature of victims' identity and community membership (Herek 2017). This is especially apparent when experienced by sexual minorities who also belong to racial and ethnic minority groups, as they may view their victimization not as a result of their sexual orientation but as a result of biases held against their racial communities (Meyer 2012). ${ }^{5}$

However, despite some evidence suggesting that sexual minorities may be less likely to report their victimization to authorities (Herek, Cogan, and Gillis 2002), Briones-Robinson, Powers, and Socia (2016) find that sexual orientation bias victims do not differ from victims of other forms of crime in reporting their victimization to the police. Instead, the type of victimization (personal v. property) and situational characteristics of the crime (e.g., crime severity) better predict reporting. Moreover, sexual orientation bias victims who did report their victimization to the police were not more likely than other bias crime victims to receive differential treatment from law enforcement. Therefore, these findings suggest that LGBT hate crime victims should not systematically differ from other bias crime victims in terms of whether they report their victimization. As such, this similarity among bias crime victims should enhance the applicability of findings regarding anti-LGBT hate crime reporting to other types of hate crimes. 


\section{STRUCTURAL FACTORS AND HATE CRIME REPORTING}

The criminological literature suggests that hate crimes, like other crimes, are more common in areas marked by poverty or social inequality, as economic conditions affect crime levels and reflect cleavages among diverse social groups (Shaw and McKay 1942; Sampson and Groves 1989; Sampson, Raudenbush, and Earls 1997; Grattet and Jenness 2008). These major explanations relate to classic paradigms associated with grievancebased approaches such as relative deprivation, social disorganization, and group/racial threat theories. Relative deprivation theory argues that bias and hate crimes may occur when individuals perceive disadvantage relative to others in terms of power, resources, or opportunities (McMahon et al. 2004). Social disorganization theory identifies how neighborhood structural conditions (e.g., poverty, ethnic heterogeneity, residential mobility, urbanization, and family disruption) undermine social cohesion and informal social control, thereby fostering crime (Sampson and Groves 1989; Gladfelter, Lantz, and Rubak 2017). Finally, group/racial threat theories argue that a large minority population makes the majority feel threatened, which eventually results in lawlessness and increased social control (King 2007). In sum, these theories would predict that poverty and population diversity would foster the occurrence of hate crimes at the local level (Gladfelter, Lantz, and Rubak 2017) and, by extension, at the state level (Smith 1997). ${ }^{6}$

For instance, hate crimes are more likely to occur in areas characterized by unemployment and poverty (Beirich 2011). ${ }^{7}$ Poverty is positively associated with the occurrence of crime and with crime control efforts (Grattet and Jenness 2008). Poor economic conditions in the form of income inequality can exist at the neighborhood, state, or national level (Weatherburn 2001). Stotzer (2010a) finds that lower median income and higher density of entertainment businesses (i.e., food, accommodations, entertainment, and recreation) predict the risk of victimization of LGB individuals. ${ }^{8}$ Anti-LGBT hate crimes may serve as a way for economically disadvantaged individuals to lessen their economic distress by attacking victims who "do not belong" or who appear to be easy targets (Stotzer 2010a). For instance, an individual's sexual orientation could serve as motivation for a bias-motivated act that eventually culminates in a robbery (Herek and Berrill 1992). Scarce resources result in competition among various social groups for jobs and threaten the economic security of certain members of a given society, which can spark tensions based on race, religion, or sexual orientation (Jenness and Grattet 1996).

The occurrence of hate crimes, however, may not reflect existing poverty and diversity, but rather changes in the population. Specifically, structural conditions can affect hate crimes based on the particular target of the hate crime (Gladfelter, Lantz, and Rubak 2017). From that perspective, we should expect that hate crimes are more likely in less disadvantaged areas that are experiencing demographic transitions (Green, Strolovitch, and Wong 1998; Lyons 2008; Gladfelter, Lantz, and Rubak 2017). As such, places that reflect diversity in sexual orientation and that are also experiencing demographic shifts should have greater incidences of anti-LGBT hate crimes (Stotzer 2010a). These conditions should be especially likely in urbanized areas (Gorman-Murray and Nash 2016), with the level of urbanization determining how often LGBT individuals frequent these areas or inhabit these locations (D'Augelli and Garnets 1995; Ghaziani 2015). For instance, Haider-Markel (2002) finds that efforts by law enforcement to reduce anti-LGBT hate crimes are more likely to occur in larger cities and in cities that contain a more visible lesbian and gay population. Therefore, states that are more highly urbanized should have more visible LGBT constituencies, which may increase the occurrence of anti-LGBT hate crimes. 
The greater the incidence of LGBT hate crimes, the greater the likelihood that law enforcement will direct efforts toward crime control, thereby increasing the number of crimes reported (Grattet and Jenness 2008). As such, the structural conditions that the criminological literature traditionally associates with the incidence of hate crimes may also be correlated with the number of hate crimes that are reported. We therefore present two hypotheses:

Hypothesis 1: States with higher levels of poverty and unemployment will have higher levels of anti-LGBT hate crime reporting.

Hypothesis 2: States with higher levels of urbanization will have higher levels of anti-LGBT hate crime reporting.

\section{SOCIAL MOVEMENT FACTORS AND HATE CRIME REPORTING}

Although the occurrence of anti-LGBT hate crimes may lead to an increase in their reporting, it may be that the crimes that occur are only identified as hate crimes if resources, and the organizations that channel these resources, are present (McVeigh, Welch, and Bjarnason 2003; Amenta and Caren 2004; Andrews and Edwards 2004; Grattet and Jenness 2008). Typically, the social movements literature has examined how local-level processes affect hate crime reporting (see McVeigh, Welch, and Bjarnason 2003). For instance, hate crime reporting depends upon the participation of law enforcement in voluntary data collection initiatives (e.g., the FBI's Uniform Crime Reporting Program) and the provision of police training to enable the proper identification of hate crimes (Herek 2017; see also Nolan and Akiyama 1999; Nolan, Akiyama, and Berhanu 2002). However, law enforcement officers are agents of the state and are responsible for upholding state and federal laws (Haider-Markel 2002). Larger state-level processes should thus influence whether agencies participate in hate crime reporting. These statelevel factors can include the political context of a state, the enactment of relevant legislation at the state and federal levels (for example, the 1990 HCSA), and pressure from advocacy groups who organize at the state level (Nolan and Akiyama 1999; Cronin et al. 2007). Below, we discuss how SMOs and the larger political context can affect the reporting of anti-LGBT hate crimes.

\section{A. ORGANIZATIONAL RESOURCE MOBILIZATION}

Previous social movement scholarship indicates that SMOs facilitate policy change through organizational capacity and the acquisition of resources (McCarthy and Zald 1977; Freeman 1983; Jenkins 1983). Specifically, SMOs can serve as conduits through which human and material resources can flow (Andrews 2001; Amenta and Caren 2004; Edwards and McCarthy 2004). SMOs can provide social movements with a strong infrastructure via membership (Andrews 2001) or density - that is, the actual number of organizations (Kane 2003; Soule and Olzak 2004). For instance, Kenneth Andrews (2001) finds that membership in SMOs facilitated the implementation of federal poverty programs in Mississippi, as these entities affected the levels of funding local counties received. Moreover, the increased presence of LGBT organizations within a state promotes LGBT rights at the state level (Haider-Markel and Meier 1996) and the likelihood that a state will include sexual orientation as a protected status in hate crime legislation (Parris and Scheuerman 2015). For instance, in a study examining the influence of legal 
change on gay and lesbian mobilization, Melinda Kane (2010, 263) argues that "organizations are a key resource for social movements; they pool resources, coordinate action, and, if maintained during movement lulls, facilitate the later resurgence of activism." The amount of resources held by these organizations may then reflect the degree to which a state directs assets toward implementation of hate crime laws (McVeigh, Welch, and Bjarnason 2003; McVeigh, Neblett, and Shafiq 2006).

The proliferation of LGBT organizations can thus serve as an indicator of movement strength (Armstrong 2002; Kane 2003, 2010). In addition to pooling resources to advocate for the demands of the LGBT community, the presence of LGBT-owned and LGBTfriendly businesses may reflect adherents who desire the implementation of policies designed to protect the LGBT population (McCarthy and Zald 1977). As such, the presence and number of LGBT organizations should foster the detection and reporting of anti-LGBT hate crimes by law enforcement (Grattet and Jenness 2008). For instance, a strong presence of LGBT SMOs at the state level could affect how police implement hate crime policy at the local level by assisting the training of law enforcement in interacting with the LGBT community. Greater hate crime reporting may then illustrate a greater willingness by victims to report crimes (which then have a greater likelihood of being included in official statistics), as victims believe that law enforcement agencies will take those crimes seriously (Nolan and Akiyma 1999; Best 2012; PFLAG 2016; for an exception, see Levy and Levy 2017). Based on the social movement literature on SMOs, we predict that

Hypothesis 3: States with larger numbers of LGBT SMOs will report higher levels of antiLGBT hate crimes.

\section{B. POLITICAL CONTEXT}

The political climate also affects social movement outcomes (Tilly 1978; Amenta, Carruthers, and Zylan 1992; Amenta, Dunleavy, and Bernstein 1994). The availability of political opportunities is especially relevant when social movements aim to influence policy (Tilly 1978; Kane 2007). Political opportunities include political openness to the demands of social movements (Amenta and Halfmann 2000), the feasibility of governments passing policies to reflect those demands (McCammon et al. 2001), as well as the presence of sympathetic elites in positions of power and splits between political elites (Kane 2003, 2007). Regarding these former types of political opportunities, the existence of political allies and larger structural opportunities within the polity have fostered the expansion of LGBT rights (Haider-Markel and Meier 1996) and the inclusion of sexual orientation in hate crime policy (Grattet, Jenness, and Curry 1998; Jenness 1999; Parris and Scheuerman 2015).

Political opportunities should also promote the implementation of hate crime legislation (Nolan and Akiyama 1999). Law enforcement agencies are more likely to accurately report hate crimes when "the local political environment views hate crime as a significant problem" (Balboni and McDevitt 2001, 4; see also Nolan and Akiyama 1999). As the local political environment depends in part on state-level processes (Goldstone 2004), we expect to find higher levels of hate crime reporting in states with more favorable political contexts (McVeigh, Neblett, and Shafiq 2006). Specifically, state governments with a liberal ideology and a strong Democratic Party presence should provide support for the detection and proper identification of crimes perpetrated due to sexual orientation. These types of governments have typically allied themselves with issues important to the LGBT movement and with securing LGBT rights (e.g., adoption and domestic partnership rights, gays and lesbians in the military, the decriminalization of sodomy laws, and 
anti-LGBT hate crime legislation) (Rayside 1998; Kane 2003; Smith 2008; Parris and Scheuerman 2015). We hypothesize that

\section{Hypothesis 4: States characterized by a favorable political context in terms of ideology or pres- ence of allies will report higher levels of anti-LGBT hate crime.}

In addition, political realignments and conflict among political elites provide openings for SMOs to enter the political arena (Tarrow 1998). States characterized by political fracturing (i.e., with different political parties controlling the legislative and executive branches) should favor social movement activity (McAdam 1982; Tarrow 1998). Ideological divisions among political elites provide opportunities for SMOs to enter political processes in ways that might not be possible under highly unified political regimes (Tarrow 1998; Kane 2003; Parris and Scheuerman 2015). In this case, states that are solidly Republican and those that are solidly Democratic may be less willing to commit law enforcement resources to LGBT hate crime reporting because those political elites face less pressure to court constituent interest groups. We therefore predict that

Hypothesis 5: States characterized by split elites will report higher levels of anti-LGBT hate crime.

\section{POLITICAL MEDIATION}

The presence of political opportunities alone, however, may not fully explain the implementation of anti-LGBT hate crime policy without also considering the presence of social movement organizations that can capitalize on such opportunities. The political mediation model put forth by Amenta and colleagues (Amenta, Carruthers, and Zylan 1992; Amenta, Dunleavy, and Bernstein 1994; Amenta, Caren, and Olasky 2005; Amenta 2006) argues that social movement outcomes are contingent upon SMOs capitalizing on the political contexts in which they operate (see also Staggenborg 1991; Werum and Winders 2001). SMOs must adapt their actions and structures to operate effectively within their specific partisan political contexts and will be more likely to meet their goals when the members of the polity believe that they will benefit in assisting the challenging group (Kane 2003). Factors affecting the receptivity of the polity include the presence of a favorable political context, political allies (Amenta, Dunleavy, and Bernstein 1994; Cress and Snow 2000; Soule and Olzak 2004; Parris and Scheuerman 2015), and the level of political divisions among elected officials (Amenta et al. 2010; Parris and Scheuerman 2015). Like others (e.g., Soule and Olzak 2004), we elaborate upon this perspective to identify how social movement organizational mobilization and political opportunities may interact to affect social movement outcomes.

The positive influence of LGBT SMOs on hate crime reporting should be strongest when they operate within a favorable political context as detailed above. For instance, at the county level, McVeigh, Welch, and Bjarnason (2003) find that civil rights organizations and resources have a greater impact on the number of hate crime reports when strong support for the Democratic Party is also present. At the state level, Parris and Scheuerman (2015) find that the effect of LGBT SMO presence on the enactment of anti-LGBT hate crime policy is dependent upon the size of the Democratic presence in the legislature. Building on this work, we argue that a Democratic majority in the state legislature, or a general liberal ideology among government officials, will enhance the positive influence that LGBT SMO presence has on the 
reporting of anti-LGBT hate crimes by providing opportunities for institutional oversight. We therefore predict that

Hypothesis 6: States with larger numbers of LGBT SMOs and a favorable political context in terms of ideology or the presence of allies will report higher levels of anti-LGBT hate crimes.

The presence of a favorable political context would suggest the absence of political divisions, as these states would "have greater capacity to implement the policies they choose to support" (Tarrow 1994, 81). In this situation, LGBT organizations would be better able to persuade members of the polity that it is in their best interest to support LGBT causes (Kane 2003). Nevertheless, the operation of SMOs may also be contingent upon the presence of split elites (Tarrow 1998; Amenta et al. 2010; Parris and Scheuerman 2015), which may either foster or hinder social movement success. Amenta et al. (2010, 298) sum it up aptly: "The centralization and division of power between each branch of government mean both multiple points of access and veto." A divided polity may provide challengers with opportunities to access the political system in ways that would not otherwise be available (Shorter and Tilly 1974; McAdam 1982). Specifically, social movements must have the ability to take advantage of a weakened political structure, including party divisions between government offices and ideological disagreements among them. This provides an opportunity through which SMOs can attempt to capitalize on political divisions by courting political allies. Implementation of anti-LGBT hate crimes, represented by their reporting, should thus be positively associated with politically divided states that have a substantial LGBT organizational presence. We therefore hypothesize that

Hypothesis 7: States with higher levels of LGBT SMOs and split elites will report higher levels of anti-LGBT hate crimes.

\section{DATA AND METHODS}

\section{A. DEPENDENT VARIABLE}

Our outcome of interest is the reporting of anti-LGBT hate crimes. This variable comes from the UCR collected by the FBI. We chose this data source because it is the longest running collection of hate crimes reported. Only recently has the National Crime Victimization Survey added questions that assess hate crimes, and not every state is certified to submit to the National Incident-Based Reporting System (Nolan, Akiyama, and Berhanu 2002). We focus on the years 1995-2008 for all fifty US states. We examine this time period due to UCR data restrictions and because federal law was expanded in 2009 to include sexual orientation as a protected status.

This measure reflects "different sources of information, different agencies applying differential definitions of hate crime, and some agencies and states not even participating in the data collection efforts" (Stotzer 2010a, 992; see also Nolan, Akiyama, and Berhanu 2002). Specifically, the dependent variable is an aggregation of anti-LGBT hate crimes reported by cities, universities and colleges, suburban counties, rural counties, state police agencies, and other agencies. We therefore interpret this count variable as reflective of each state's willingness to report and not as a measure of the actual number of anti-LGBT hate crimes that occur (Grattet and Jenness 2008; King, Messner, and Baller 2009; Herek 2017). Between 1995 and 2008, 16,712 anti-LGBT hate crimes were reported across states (see Table 1 for all descriptive statistics). ${ }^{9}$ 
Table 1. Summary Statistics

\begin{tabular}{|c|c|c|c|c|c|}
\hline & Obs. & Mean & S.D. & Minimum & Maximum \\
\hline \multicolumn{6}{|l|}{ Dependent Variable } \\
\hline LGBT Hate Crimes Reported & 678 & 24.65 & 50.41 & 0 & 436 \\
\hline \multicolumn{6}{|l|}{ Independent Variables } \\
\hline Per Capita Disposable Income & 700 & 96.66 & 12.48 & 74.3 & 135.2 \\
\hline Unemployment & 700 & 4.78 & 1.16 & 2.20 & 8.40 \\
\hline Urbanization & 700 & 71.83 & 14.87 & 36.57 & 95.04 \\
\hline LGBT SMOs & 700 & 13.24 & 9.58 & 1.91 & 74.49 \\
\hline Government Ideology & 700 & 45.80 & 26.95 & 0.60 & 104.04 \\
\hline Democrats & 700 & 76.40 & 36.30 & 12 & 253 \\
\hline Split Elites $(1=$ Split $; 0=$ Not Split $)$ & 700 & 0.45 & 0.50 & 0 & 1 \\
\hline \multicolumn{6}{|l|}{ Control Variables } \\
\hline Serious Crime & 700 & 4094.87 & 1105.52 & 1791.00 & 8214.00 \\
\hline Percent Nonwhite & 700 & 23.75 & 14.82 & 1.74 & 77.1 \\
\hline Population Density & 700 & 182.61 & 247.49 & 1.10 & 1176.20 \\
\hline Population 18-24 & 700 & 549.88 & 611.24 & 50.00 & 3854.00 \\
\hline Education & 700 & 25.23 & 4.94 & 11.86 & 39.12 \\
\hline South $(1=$ South; $0=$ Other Regions $)$ & 700 & 0.32 & 0.47 & 0 & 1 \\
\hline Midwest ( $1=$ Midwest; $0=$ Other Regions) & 700 & 0.24 & 0.43 & 0 & 1 \\
\hline $\begin{array}{l}\text { Passage of Anti-LGBT Hate Crime Laws }(1=\text { Yes; } \\
0=\mathrm{No})\end{array}$ & 700 & 0.62 & 0.49 & 0 & 1 \\
\hline
\end{tabular}

\section{B. INDEPENDENT VARIABLES}

We examine how state-level structural and social movement variables affect anti-LGBT hate crime reporting. Each variable is measured annually at the state level.

\section{Structural Variables}

Since anti-LGBT hate crimes and their reporting should be positively associated with low socioeconomic status and urbanization, we include three measures that come from the US Census Bureau's Statistical Abstracts. The first two measures reflect economic conditions: affluence and unemployment. Affluence is measured by the yearly per capita disposable income of each state as the percentage of the US average, while unemployment is measured by the annual state unemployment rate. The third measure assesses annual state-level urbanization, identifying the percentage of state residents residing in urban areas. We compiled data for each of these variables using yearly Census reports for each state. Higher values on these three measures indicate less poverty, greater unemployment, and greater urbanization, respectively.

\section{Social Movements Variables}

LGBT social movement organizational mobilization: Constructed by Kane (2010) and expanded by Parris and Scheuerman (2015), our measure of social movement organizational mobilization represents the number of LGBT advocacy organizations per capita, per state year. Information for this variable comes from The Gayellow Pages. Published since 1973, The Gayellow Pages serves as a guide to the LGBT community and reflects information on social movement organizations, LGBT-owned and LGBT-friendly business, publications, law services, chapters of the ACLU and PFLAG, and nonprofit organizations (Kane 2010). Both political and general pride organizations are included, and 
each organization is weighted equally. The number of LGBT organizations in a state may reflect diversity and the degree to which the population of the state can mobilize resources and work together for a common goal, which should increase the reporting of anti-LGBT hate crimes.

Political Opportunities: The level of anti-LGBT hate crime reporting in a particular state and time also depends on the openness of the political environment toward the LGBT movement. We use two measures of government ideology to assess the presence of potential movement allies within the government. The first measure evaluates the degree of liberalism and conservatism among political leaders by using a scale that ranges from zero to 100, with higher numbers indicating higher levels of liberalism (see Berry et al. 1998). We also measure the number of Democrats in the combined upper and lower houses of the state legislature as reported in the Statistical Abstracts of the United Sates. ${ }^{10}$ In addition, we include a measure of split elites by identifying whether the political party of the governor differs from that of the majority party of the state legislature. This measure is a dummy variable coded " 1 " when the governorship and legislature are controlled by different parties, thus indicating the presence of split elites.

Political Mediation: As we also posit that resources and political opportunities will interact to affect the reporting of anti-LGBT hate crimes, we created three multiplicative interaction terms. Continuous variables were mean-centered prior to forming these interactions (Aiken and West 1991; Williams 2015). Our measure of LGBT SMOs is multiplied respectively with our measures of (1) government ideology, (2) number of Democrats in the state legislature, and (3) political divisions. We expect that the positive effect of LGBT SMO-mobilization on the reporting of anti-LGBT hate crimes will be strongest in states that have a liberal ideology, a greater number of Democrats, and the presence of split elites.

\section{CONTROLS}

Unless otherwise specified, our controls come from the US Census Bureau's Statistical Abstracts. To understand the factors that specifically affect the reporting of hate crimes, we control for a range of variables that may positively affect the occurrence of crime in general (see Shaw and McKay 1942; Felson 1994; Jenness and Grattet 1996; McVeigh, Welch, and Bjarnason 2003; Stotzer 2010a). These variables include serious crime rate per 100,000 (murder, forcible rape, robbery, aggravated assault, burglary, larceny, and motor vehicle theft), population density (per square mile of land area), and the rate per 1,000 of individuals aged eighteen to twenty-four in the population. We also control for the percentage of the population that has obtained at least a college degree because education and acceptance of homosexuality are positively correlated (Loftus 2001). Additionally, due to geographic variation regarding many of our independent variables and the influence of region on the reporting of hate crimes (King 2007), we include the census region of each state as a control variable. Based on regional census categories, we created a dummy measure for the South and Midwest, as southern and midwestern states are less likely than northeastern and western states to participate in the HCSA (McVeigh, Welch, and Bjarnason 2003). As such, our results should be interpreted in comparison to the Northeast and West.

Last, we control for states that have passed anti-LGBT hate crime policy. We include this variable as a control to assess how our independent variables solely affect 
implementation, as certain of these same variables have been associated with policy passage. To be sure, anti-LGBT hate crime policy should be indicative of a favorable political climate (Parris and Scheuerman 2015). Nevertheless, states with these laws may bias the relationship between LGBT social movement organizational mobilization and the number of hate crimes that are reported (McVeigh, Neblett, and Shafiq 2006; Grattet and Jenness 2008). We thus created a dummy variable coded " 1 " for those states that had adopted anti-LGBT hate crime legislation. ${ }^{11}$ Thirty-one states during this time period (1995-2008) had state hate crime statutes that criminalized acts perpetrated against others on the basis of sexual orientation. ${ }^{12}$

\section{ANALYTICAL STRATEGY}

We employ negative binomial regressions to assess our hypotheses, as our outcome variable is a count variable that is overly dispersed (Long 1997). Specifically, we use fixedeffects negative binomial regressions that account for panel data. Fixed-effects negative binomial regressions enable one to assess the influence of time variant variables on the outcome of interest by controlling for time invariant variables (Torres-Reyna 2007). ${ }^{13}$ Here, our models include state and year fixed effects. We interpolated missing data for some of our variables (government ideology, urbanization, percent nonwhite,

Table 2. Negative Binomial Regressions of Structural and Social Movement Factors Affecting Number of Anti-LGBT Hate Crime Reports, 1995-2008

\begin{tabular}{|c|c|c|c|c|}
\hline & Model 1 & Model 2 & Model 3 & Model 4 \\
\hline \multicolumn{5}{|l|}{ Structural Factors } \\
\hline $\begin{array}{l}\text { Per Capita Disposable } \\
\text { Income }\end{array}$ & $-.004(.007)$ & & & \\
\hline Unemployment & $-.045(.032)$ & & & \\
\hline Urbanization & $.042(.011)^{* * *}$ & & & \\
\hline \multicolumn{5}{|l|}{ SMO Mobilization } \\
\hline LGBT SMOs & & $.005(.006)$ & & $.004(.006)$ \\
\hline \multicolumn{5}{|l|}{ Political Opportunities } \\
\hline $\begin{array}{l}\text { Government Ideology } \\
\text { (GI) }\end{array}$ & & & $.001(.001)$ & $.001(.001)$ \\
\hline Democrats & & & $-.003(.002)$ & $-.003(.002)$ \\
\hline Split Elites & & & $-.008(.044)$ & $-.006(.044)$ \\
\hline \multicolumn{5}{|l|}{ Controls } \\
\hline Serious Crime & $.000(.000)^{* *}$ & $.000(.000)^{* * *}$ & $.000(.000)^{* * *}$ & $.000(.000)^{* * *}$ \\
\hline Percent Nonwhite & $-.042(.011)^{* * *}$ & $-.019(.010)^{*}$ & $-.022(.009)^{*}$ & $-.021(.009)^{*}$ \\
\hline Population Density & $.001(.001)$ & $.001(.000)^{* *}$ & $.001(.000)^{* *}$ & $.001(.000)^{* *}$ \\
\hline Population 18-24 & $.000(.000)$ & $.000(.000)^{+}$ & $.000(.000)^{*}$ & $.000(.000)^{*}$ \\
\hline Education & $-.011(.010)$ & $-.001(.011)$ & $.001(.010)$ & $.001(.011)$ \\
\hline South & $-.214(.218)$ & $-.421(.199)^{*}$ & $-.405(.206)^{*}$ & $-.394(.205)^{+}$ \\
\hline Midwest & $.198(.303)$ & $.409(.295)$ & $.392(.298)$ & $.408(.299)$ \\
\hline $\begin{array}{c}\text { Passage of Anti-LGBT } \\
\text { Hate Crime Laws }\end{array}$ & $.347(.246)$ & $.396(.238)^{+}$ & $.456(.228)^{+}$ & $.398(.243)$ \\
\hline Log-Likelihood & -1851.77 & -1858.76 & -1857.69 & -1857.44 \\
\hline Wald $\chi^{2}$ & $145.51 * * *$ & $127.78^{* * *}$ & $128.48 * * *$ & 129.69 \\
\hline Number of Observations & 678 & 678 & 678 & 678 \\
\hline Number of Groups & 50 & 50 & 50 & 50 \\
\hline
\end{tabular}

Note: Standard errors are reported in parentheses; ${ }^{+} p \leq .10,{ }^{*} p \leq .05,{ }^{* *} p \leq .01,{ }^{* * *} p \leq .001$ (two-tailed). 
population aged eighteen to twenty-four, and education). These variables were first logged and then interpolated within each state by panel. Upon linear interpolation, we took the antilog of the interpolated variables. We used this strategy because logarithmic transformation produces more accurate results when using linear interpolation (Olkin, Gibbons, and Sobel 1999). We present summary statistics of our variables in Table 1.

Tables $2-4$ present our negative binomial regression models. ${ }^{14}$ The first three models of Table 2 examine whether structural variables, LGBT SMOs, and political opportunities affect anti-LGBT hate crime reporting, while Model 4 investigates whether LGBT SMOs and political opportunities separately and uniquely predict the reporting of antiLGBT hate crimes. Table 3 includes Models $5 \mathrm{a}-\mathrm{c}$, which examine whether resources and political opportunities interact to affect the implementation of anti-LGBT hate crime policy. Finally, Table 4 accounts for both political mediation and structural factors in affecting the reporting of anti-LGBT hate crimes. ${ }^{15}$

\section{RESULTS}

As seen in Table 2, urbanization $(b=.042 ; p \leq .001)$ is the only structural factor that affects anti-LGBT hate crime reporting, which supports Hypothesis 2 but does not support Hypothesis 1 (regarding poverty and unemployment). States with high levels of urbanization may allow for greater diversity in sexual orientation, which could increase the incidence and reporting of anti-LGBT hate crimes (D'Augelli and Garnets 1995; Stotzer 2010a; Ghaziani 2015; Gorman-Murray and Nash 2016). Additionally, in contrast to expectations, Hypotheses 3 through 5 are not supported. Ongoing advocacy efforts on the part of SMOs (Hypothesis 3) and political opportunities due to favorable political contexts (Hypothesis 4) and split elites (Hypothesis 5) do not affect antigay hate crime reporting.

Regarding our controls, it appears that anti-LGBT hate crimes are more likely to be reported in states that are outside of the South and that have lower levels of racial diversity. Southern states may be more likely to underreport anti-LGBT hate crimes due to their reduced participation in hate crime reporting (McVeigh, Welch, and Bjarnason 2003). Moreover, racial diversity may have a negative association with anti-LGBT hate crime reporting because the intersection of race and sexuality may make it more difficult for victims to determine why they were victimized (Meyer 2008). Lastly, states with higher levels of crime, greater population density, and more individuals aged eighteen to twenty-four are more likely to report anti-LGBT hate crimes. This could be due to the fact that these latter conditions correlate with the occurrence of crime in general (Smith 1997; McVeigh, Welch, and Bjarnason 2003).

Political opportunities, rather than affecting the reporting of anti-LGBT hate crimes independently, interact with LGBT SMOs to affect the enforcement of laws concerning this type of crime (Table 3). Specifically, in support of Hypothesis 7 but not 6 (concerning the interaction between SMOs and a favorable political context), the presence of a divided polity interacts with LGBT SMOs to facilitate anti-LGBT hate crime reporting $(b=.013 ; p \leq .01$, Model $5 \mathrm{c}$ ). Figure 1 illustrates this relationship by presenting the predictive margins or expected values from the interaction. As expected, at higher levels of LGBT social movement organizational mobilization, states characterized by political divisions are significantly different from those that are not. That is, those states that have split elites are more likely to report anti-LGBT hate crimes. This interaction effect holds when accounting for structural factors and may assist in explaining two marginally significant findings: the first being the negative association 
Table 3. Negative Binomial Regressions of Political Mediation Affecting Number of Anti-LGBT Hate Crime Reports, 1995-2008

\begin{tabular}{|c|c|c|c|}
\hline & Model 5a & Model 5b & Model 5c \\
\hline \multicolumn{4}{|l|}{ SMO Mobilization } \\
\hline LGBT SMOs & $.001(.007)$ & $.003(.006)$ & $.000(.007)$ \\
\hline \multicolumn{4}{|l|}{ Political Opportunities } \\
\hline Government Ideology (GI) & $.001(.001)$ & $.001(.001)$ & $.001(.001)$ \\
\hline Democrats & $-.003(.002)^{+}$ & $-.003(.002)^{*}$ & $-.002(.002)$ \\
\hline Split Elites & $.000(.044)$ & $-.002(.044)$ & $-.009(.044)$ \\
\hline \multicolumn{4}{|l|}{ Political Mediation } \\
\hline LGBT SMOs * GI & $.000(.000)$ & & \\
\hline LGBT SMOs * Democrats & & $.000(.000)$ & \\
\hline LGBT SMOs * Split Elites & & & $.013(.005)^{* *}$ \\
\hline \multicolumn{4}{|l|}{ Controls } \\
\hline Serious Crime & $.000(.000)^{* * *}$ & $.000(.000)^{* * *}$ & $.000(.000)^{* * *}$ \\
\hline Percent Nonwhite & $-.022(.009)^{*}$ & $-.021(.009)^{*}$ & $-.019(.010)^{+}$ \\
\hline Population Density & $.001(.000)^{* *}$ & $.001(.000)^{* *}$ & $.001(.000)^{* *}$ \\
\hline Population $18-24$ & $.000(.000)^{*}$ & $.000(.000)^{*}$ & $.000(.000)^{+}$ \\
\hline Education & $.002(.011)$ & $.001(.011)$ & $.000(.011)$ \\
\hline South & $-.416(.204)^{*}$ & $-.399(.205)^{+}$ & $-.367(.205)^{+}$ \\
\hline Midwest & $.385(.299)$ & $.370(.297)$ & $.392(.294)$ \\
\hline $\begin{array}{l}\text { Passage of Anti-LGBT Hate } \\
\text { Crime Laws }\end{array}$ & $.376(.243)$ & $.378(.243)$ & $.399(.243)$ \\
\hline Log-Likelihood & -1856.60 & -1856.60 & -1853.78 \\
\hline Wald $\chi^{2}$ & $131.20 * * *$ & $131.01 * * *$ & $136.50 * * *$ \\
\hline Number of Observations & 678 & 678 & 678 \\
\hline Number of Groups & 50 & 50 & 50 \\
\hline
\end{tabular}

Note: Standard errors are reported in parentheses; ${ }^{+} p \leq .10, * p \leq .05, * * p \leq .01, * * * p \leq .001$ (two-tailed).

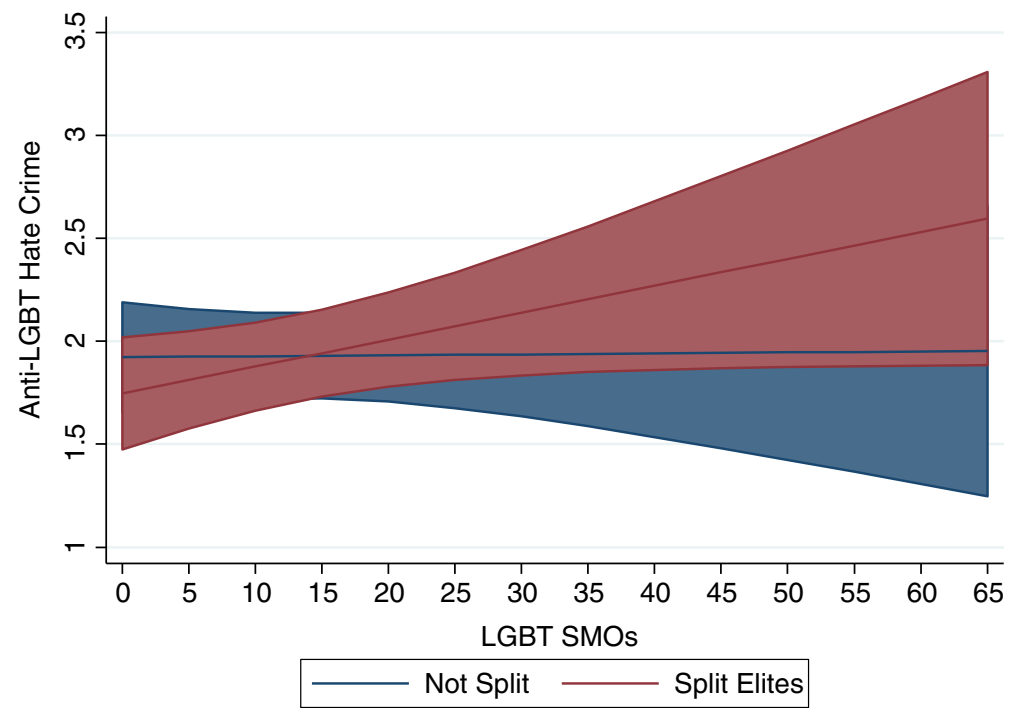

Figure 1. Predictive Margins of the Interaction Effect of LGBT SMOs and Split Elites on Hate Crime Enforcement with 95 Percent Confidence Intervals.

between Democrats in the state legislature and anti-LGBT hate crime reporting (Table 3), and the second reflecting the positive interaction effect of LGBT SMOs and government ideology on anti-LGBT hate crime reporting (Table 4). Rather than an 
Table 4. Negative Binomial Regressions of Political Mediation and Structural Factors Affecting Number of Anti-LGBT Hate Crime Reports, 1995-2008

\begin{tabular}{|c|c|c|c|}
\hline & Model 6a & Model 6b & Model 6c \\
\hline \multicolumn{4}{|l|}{ Structural Factors } \\
\hline Per Capita Disposable Income & $-.003(.007)$ & $-.003(.007)$ & $-.005(.007)$ \\
\hline Unemployment & $-.040(.032)$ & $-.042(.032)$ & $-.048(.032)$ \\
\hline Urbanization & $.044(.012)^{* * *}$ & $.042(.012)^{* * *}$ & $.042(.012)^{* * *}$ \\
\hline \multicolumn{4}{|l|}{ SMO Mobilization } \\
\hline LGBT SMOs & $.000(.007)$ & $.003(.006)$ & $-.001(.007)$ \\
\hline \multicolumn{4}{|l|}{ Political Opportunities } \\
\hline Government Ideology (GI) & $.001(.001)$ & $.001(.001)$ & $.000(.001)$ \\
\hline Democrats & $-.002(.002)$ & $-.003(.002)$ & $-.001(.002)$ \\
\hline Split Elites & $.009(.043)$ & $.004(.042)$ & $-.002(.042)$ \\
\hline \multicolumn{4}{|l|}{ Political Mediation } \\
\hline LGBT SMOs * GI & $.000(.000)^{+}$ & & \\
\hline LGBT SMOs * Democrats & & $.000(.000)$ & \\
\hline LGBT SMOs * Split Elites & & & $.015(.005)^{* *}$ \\
\hline \multicolumn{4}{|l|}{ Controls } \\
\hline Serious Crime & $.000(.000)^{*}$ & $.000(.000)^{*}$ & $.000(.000)^{*}$ \\
\hline Percent Nonwhite & $-.044(.011)^{* * *}$ & $-.042(.011)^{* * *}$ & $-.041(.011)^{* * *}$ \\
\hline Population Density & $.001(.001)$ & $.001(.001)$ & $.001(.001)$ \\
\hline Population $18-24$ & $.000(.000)^{*}$ & $.000(.000)^{+}$ & $.000(.000)$ \\
\hline Education & $-.008(.011)$ & $-.008(.011)$ & $-.008(.011)$ \\
\hline South & $-.194(.225)$ & $-.178(.227)$ & $-.145(.226)$ \\
\hline Midwest & $.179(.307)$ & $.178(.305)$ & $.181(.303)$ \\
\hline Passage of Anti-LGBT Hate Crime Laws & $.267(.255)$ & $.289(.256)$ & $.334(.255)$ \\
\hline Log-Likelihood & -1849.45 & -1849.93 & -1846.67 \\
\hline Wald $\chi^{2}$ & $149.98 * * *$ & $150.08 * * *$ & $153.50 * * *$ \\
\hline Number of Observations & 678 & 678 & 678 \\
\hline Number of Groups & 50 & 50 & 50 \\
\hline
\end{tabular}

Note: Standard errors are reported in parentheses; ${ }^{+} p \leq .10,{ }^{*} p \leq .05,{ }^{* *} p \leq .01,{ }^{* * *} p \leq .001$ (two-tailed).

ideologically favorable political context, political friction, as it relates to split political parties, drives anti-LGBT hate crime reporting when LGBT SMOs are present. Finally, even when accounting for social movement influences, urbanization remains a significant predictor of anti-LGBT hate crime reporting (Table 4).

\section{DISCUSSION}

Our analyses make multiple contributions to research on hate crime policy implementation. First, rather than examining hate crime reports locally, we examine how structural variables identified by criminologists and social movement variables affect antiLGBT hate crime reporting at the state level. Doing so allows us to assess whether state-level processes affecting hate crime policy enforcement are like those at other levels of analysis. Second, we build on existing social movement literature to expand the conceptualization of movement outcomes. Rather than viewing the passage of anti-LGBT hate crime legislation as the end goal, we ask how ongoing advocacy efforts to implement those policies succeed or fail. In so doing, we also illustrate another dimension of social movements' political consequences (McVeigh, Welch, and Bjarnason 2003; Amenta et al. 2010; Barclay, Jones, and Marshall 2011) and add nuance to our understanding of the conditions under which movements "succeed." 
Finally, we test how conditions that affect policy passage also affect policy implementation to see whether similar or different processes operate to affect the creation and enforcement of hate crime policy.

Ultimately, we find that a combination of structural and social movement variables contribute to anti-LGBT hate crime reporting. Specifically, states that have higher levels of urbanization are more likely to report these crimes. This highlights an important distinction between hate crime policy implementation in general and the case of LGBT hate crimes in particular (Haider-Markel 1998) - namely, LGBT hate crimes will have a greater likelihood of being reported because urbanized areas tend to have higher concentrations of LGBT individuals (D'Augelli and Garnets 1995; Ghaziani 2015; GormanMurray and Nash 2016). These states would thus have more highly visible LGBT populations, which would indicate greater diversity based on sexual orientation and increase the occurrence and reporting of anti-LGBT hate crimes.

Urbanized areas can also undergo demographic transitions related to sexual orientation that can affect anti-LGBT hate crime reporting. Similar to the logic of group/racial threat theories in the criminological literature (Gladfelter, Lantz, and Rubak 2007; Grattet 2009), the movement of sexual minorities into heterosexual public space may affect the likelihood of anti-LGBT victimization (Stotzer 2010). Future research is needed to assess how demographic shifts among sexual minorities can influence the occurrence and reporting of anti-LGBT hate crimes at the state level.

Our results also suggest that hate crime reports are influenced by social movement processes. Here, our findings indicate that, unlike conditions favoring policy passage (Parris and Scheuerman 2015), effective policy implementation is associated with a robust LGBT SMO presence and the existence of split elites in the state. Therefore, the effect of LGBT SMOs on antigay hate crime reporting is contingent upon political fracturing in which control of the legislative and executive branches is split between Democrats and Republicans, forcing parties to compete for constituent support (see also McVeigh, Welch, and Bjarnason 2003). Our findings thus suggest that SMOs are a crucial element of policy implementation but that they are most effective when they can exploit political divisions to put consistent pressure on state governments to take their concerns seriously.

These findings have both broad and specific implications for the social movement literature. Broadly, while previous social movement research often operationalizes social movement "success" as policy passage, we consider ongoing efforts to implement policy once it is passed. Because various actors within law enforcement may view certain policies as merely symbolic, ongoing social movement efforts are necessary to ensure policy implementation (Amenta et al. 2010). Previous research on the relationship between policy implementation and SMOs indicates that SMOs are needed to support and monitor stakeholder consultation (Sturdy, Smith-Merry, and Freeman 2012), capacity-building (Coe 2012; Gibson 2017), and program funding. These efforts are strengthened by strong SMO infrastructures, including leadership, preexisting social networks, and access to resources (Andrews 2001).

Specifically, our results add to the limited scholarship on the implementation of hate crime policy at the state level. Unlike Haider-Markel's (1998) study on state efforts to implement federal hate crime policy, which focused on bias crime in general, we find a significant association between urbanism and anti-LGBT hate crime reports. In addition, we extend Haider-Markel's work by discovering that state efforts to implement hate crime policy are affected by LGBT interest groups and by political opportunities. Haider-Markel (1998) did not examine whether an interaction between split elites (i.e., party competition) and gay interest groups affected the percentage of the 
population covered by law enforcement agencies voluntarily reporting hate crimes. The author thus concluded that gay interest groups and party competition drive policy passage and implementation, with the latter variable having a reduced influence on implementation compared with passage. We thus build upon Haider-Markel's (1998) study by indicating that the interest group strength of LGBT groups (here represented by LGBT SMO mobilization) matters for predicting anti-LGBT hate crime policy implementation when political opportunities are also present.

By finding that the reporting of anti-LGBT hate crimes reflects state-level conditions, we highlight avenues for future research that assess how local- and national-level factors also affect anti-LGBT hate crime policy implementation. For instance, state-level data overlook intrastate differences in hate crime reporting and factors that affect hate crime implementation (McVeigh, Welch, and Bjarnason 2003; McVeigh, Neblett, and Shafiq 2006). As such, scholars might examine whether measures of the mobilization of LGBT organizations represent that of a hierarchal multiorganizational field in which local, state, and national organizations interact. While previous work has considered hate crime reporting and multiorganizational fields at the county level (McVeigh, Neblett, and Shafiq 2006), we submit that examining the ways in which state and local organizations interact with national organizations (e.g., HRC, Lambda Legal, and PFLAG) is analytically fruitful. By collaborating with federal SMOs, local organizations may be able to funnel resources into communities to pressure local officials to take hate crimes seriously (Minkoff 1997).

Moreover, within this hierarchical structure, a variety of LGBT SMOs might be operating. Researchers should examine whether certain types of LGBT SMOs affect policy implementation differently. Here, we cast a broad net with our inclusion parameters for our measure of organizational movement mobilization, and the heterogeneity of the organizations (i.e., news publications, legal services, and LGBT-owned and LGBTfriendly businesses) may be a key component of working with politically split elites. Various types of organizations reflect myriad cultural and political interests, leading to greater opportunities for citizens to become involved in LGBT politics. For instance, gay bars, bookstores, reproductive/insemination services, youth drop-in centers, and travel publications may attract widely heterogeneous LGBT patrons. This provides broader opportunities to recruit new members and pool resources across wide swaths of those who identify as LGBT. Also, while gay business owners may have easy access to economic and political elite allies (Bernstein 1997), organizations such as HRC and PFLAG may be more skilled at institutionalized social movement tactics (e.g., awareness raising and lobbying). Pooling these resources across different types of LGBT organizations is ultimately a more productive strategy (Curtis and Zurcher 1973). When coupled with state-level political fracturing, political elites may more acutely feel the political will of these organizations, leading to higher rates of hate crime reporting.

Overall, our findings indicate the importance of understanding the role of the citizenry in affecting policy implementation at the state level. States that are most likely to report anti-LGBT hate crimes are those that presumably have a higher concentration of sexual minorities (i.e., those that are highly urbanized), a greater degree of LGBT social movement organizational mobilization, and political tumult, which seems to make those in positions of power more receptive to LGBT interests (Haider-Markel 2002; McVeigh, Welch, and Bjarnason 2003; Kane 2007). As such, while a larger LGBT population and the presence of special interest groups may make the LGBT community a target for victimization (Stotzer 2010a), it also makes it a constituency that is able to pressure elected officials and bureaucrats (Haider-Markel 2002). And, with support for LGBT rights 
increasing over time (Adamczyk and Liao 2019), it could be that elected officials will be further amenable to citizen preferences to direct resources and efforts toward the protection of marginalized groups, thereby affecting the reporting of anti-LGBT hate crimes and, by extension, hate crimes in general (Briones-Robinson, Powers, and Socia 2018). Based on the historical specificity of views of the LGBT community, it would behoove scholars to research other state-level factors associated with anti-LGBT hate crime reporting during other time periods, especially accounting for recent advances in LGBT rights (e.g., the legalization of same-sex marriage) (Adamczyk and Liao 2019).

Despite the implications of our findings, our research is not without limitations. First, there may be factors that affect the incidence and reporting of anti-LGBT hate crime at the state level other than what we have accounted for in our study. For instance, a state's level of religious conservatism could affect the incidence and reporting of antiLGBT hate crime. Specifically, incidences of antigay hate crime may be more likely to occur in those states that have high concentrations of Protestant fundamentalists, as these denominations are most strongly associated with antigay religious beliefs (Herek 1989; Haider-Markel 2002; Lazar and Hammer 2018). Nevertheless, since the enforcement of hate crimes is reflective of public preferences, these crimes may not be reported or detected due to the reduction of state-level and, by extension, local-level efforts to combat hate crimes (Haider-Markel 2002).

Second, research is also needed to compare how structural and social movement factors predict hate crime reporting using data collected from a range of sources. In addition to official agencies, scholars should examine hate crime data collected by antiviolence organizations and community, state, and national surveys (Herek 2017). Doing so would enable researchers to better assess how structural factors and advocacy efforts affect measures of bias crimes.

Third, we cannot address the mechanisms through which SMO presence affects statelevel policy enactment when political opportunities are present. While our research addresses state-level processes, future research should examine how organizational-level phenomena, such as awareness raising, lobbying, and/or judicial litigation, affect antiLGBT hate crime reporting. Such tactical repertoires vary across local, state, and national organizations, as well as across institutionalized and disruptive SMOs. For example, state-level organizations concerned with marriage equality focused on a cultural shift - that is, changing the hearts and minds of the public - in the early 2000s, laying the groundwork for state-level litigation (Goldberg 2015). Goldberg (2015, 164) notes that "with every new victory in a court or legislature, more gay couples - and more non-gay allies-loudened their call for marriage." Given this synergistic relationship between cultural and political organizations leading up to Obergefel v. Hodges (2015), it would likely be worthwhile to examine such organizational tactics and relationships among SMOs concerned with anti-LGBT hate crime policy as well.

Last, we do not account for the effect of hate groups within states (see McVeigh, Welch, and Bjarnason 2003). Although hate crimes do not correlate with the geographic presence of hate groups (Beirich 2011), those groups may influence the reporting of hate crimes. States with a high concentration of hate groups may underreport anti-LGBT hate crimes because victims are more reluctant to report their victimization to law enforcement.

Regardless of these limitations, our research highlights that the implementation of anti-LGBT hate crime policy over time is affected not only by the level of urbanization of a given state but also by the density of SMOs and the presence of political opportunities. Urbanization may foster the development of LGBT SMOs by affecting where LGBT populations frequent and live, which has implications for the occurrence and 
reporting of anti-LGBT hate crimes. The reporting of these crimes is also more likely when SMOs have increased access to the polity due to divisions between the executive and legislative branches of state governments. Expanding upon these findings to identify local- and national-level factors that affect the reporting of this type of bias crime should be the domain of future research.

\section{NOTES}

1. Like others, we consider social movement outcomes to include cultural and political shifts, as movements may secure collective benefits ranging from cultural acceptance to policy protections (Amenta et al. 2010). Here, we focus on the political outcomes of the LGBT movement by investigating how movements influence policy implementation once a beneficial policy has passed at the state level.

2. This figure includes twenty-four antiheterosexual crimes. The Hate Crime Statistics Act of 1990, amended in 2009 by the Matthew Shepard and James Byrd Jr. Hate Crime Prevention Act, defines sexual orientation as "consensual homosexuality or heterosexuality" (UCR 2015). The Hate Crime Data Collection Guidelines and Training Manual of the FBI (2015, 15) expands upon this definition: sexual orientation is the "term for a person's physical, romantic, and/or emotional attraction to members of the same and/or opposite sex, including lesbian, gay, bisexual, and heterosexual (straight) individuals."

3. As of this writing, thirty states have hate crime statutes that recognize anti-LGBT hate crimes (Human Rights Campaign [HRC] 2018).

4. Pennsylvania overturned legislation that protected against crimes committed on the basis of sexual orientation in 2008 (HRC 2008). However, the effect of this legislation on antigay hate crimes may not be detected, as our end point is 2008. The inclusion or exclusion of Pennsylvania in our analyses does not affect our results.

5. The intersection of race and sexual orientation may lead LGBT people of color to have more difficulty assessing whether their victimization was due to their race or ethnicity or their sexual orientation, thus leading to the potential overrepresentation of white gay men in hate crime reports (Meyer 2008).

6. Determinants of crime that are invariant across time and level of analysis include population size and density, wealth and ethnic homogeneity, divorce, unemployment, and the "relative youth" of a population (Smith 1997, 352). In keeping with these theoretical traditions and our unit of analysis, we examine how poor economic conditions and population characteristics might foster hate crime reporting by promoting the occurrence of these crimes.

7. This same report revealed that hate crimes do not correlate with the number of hate groups in a locality. We thus do not control for this factor in our analyses (Beirich 2011).

8. Stotzer (2010a) does not include the "T" for transgender because data used in the author's study did not include transgender individuals.

9. Data for Hawaii reflect the number of bias-type instances rather than the actual number of hate crimes. Hawaii does not report hate crime data to the UCR and compiles this information through its Department of the Attorney General. These crimes thus reflect antigay hate crimes that have led to conviction. Moreover, Hawaii began recording hate crimes in 2002. Prior to this date, in 2001, a highly publicized incident occurred during which two young men attacked gay campers (Criminal Justice Data Brief 2003). These men eventually pled guilty to charges associated with this event and this incident is recorded in our data (DeWitt, Glassman, and Harris 2001). We therefore do not have data for Hawaii for the following five-year period of 1995-2000.

10. Due to Nebraska's nonpartisan state legislature, we were unable to collect data for that state (US Census Bureau 2008). As such, we entered 24.5 for all years for the number of Republicans and Democrats in the house (refer to Parris and Scheuerman 2015).

11. Although the District of Columbia has legislation that protects against anti-LGBT hate crimes, we do not include it in our analyses. Including Washington, DC, would likely skew our analysis as it serves as the headquarters for special interest groups (e.g., the NGLTF and the HRC), which might increase the likelihood that sexual orientation bias crimes are recognized and reported. 
12. The states that did not have legislation protecting against anti-LGBT hate crime were Alabama, Alaska, Arkansas, Georgia, Idaho, Indiana, Michigan, Mississippi, Montana, North Carolina, North Dakota, Ohio, Oklahoma, South Carolina, South Dakota, Utah, Virginia, West Virginia, and Wyoming.

13. Although the presence of zeroes suggests that zero-inflated negative binomial regression models would also be appropriate, only approximately 8 percent of the dependent variable consisted of zeroes, and a comparison of these models with that of negative binomial regression indicates that they perform very similarly (STATA 2015).

14. Since panel, or time series, data are dependent upon time, we do not present correlations, which assume the independence of observations (Riggs and Lalonde 2017).

15. Multicollinearity was not an issue in our models as all variance inflation factor (VIF) values were below 4. The only exceptions to this trend occur for urbanization in Model 1 (VIF $=4.20$ ) and when we model both political mediation and structural factors in Models 6a-c $(\mathrm{VIF}=6.61,6.54$, and 6.51 , respectively $)$.

HeAther L. SCheuerman is an Associate Professor in the Department of Justice Studies at James Madison University. She conducts interdisciplinary research that focuses on the experience of (in)justice specifically and broadly. Her recent work related to hate crimes has appeared in Research in Social Movements, Conflicts and Change.

CHRISTIE L. PARRIS is an Assistant Professor of Sociology at Oberlin College. Her research interests focus primarily on perceptions of injustice and social movements. Her work has appeared in journals such as Research in Social Movements, Conflicts and Change; Social Justice Research; and International Journal of Sustainability in Higher Education.

ALISON H. FAUPEL works for the US Department of State. During her ten years in the US government, she has focused her analysis on social movements, political stability, and democratization, with a focus on Africa. Her work has been published in Social Forces; Mobilization; and Research in Social Movements, Conflicts and Change.

REGINA WERUM is a Professor of Sociology at the University of Nebraska-Lincoln. Her research concerns political sociology and the sociology of education, especially relating to inequality in outcomes. Her recent work has appeared in Mobilization; Research in Social Stratification and Mobility; and the Journal of Family Issues.

\section{REFERENCES}

Adamczyk, Amy, and Yen-Chiao Liao. 2019. "Examining Public Opinion about LGBTQ-Related Issues in the United States and across Multiple Nations." Annual Review of Sociology 45:1-23.

Agnone, Jon. 2007. "Amplifying Public Opinion: The Policy Impact of the US Environmental Movement." Social Forces 85 (4): 1593-620.

Aiken, Leona S., and Stephen G. West. 1991. Multiple Regression: Testing and Interpreting Interactions. Thousand Oaks, CA: Sage.

Amenta, Edwin. 2006. When Movements Matter: The Townsend Plan and the Rise of Social Security. Princeton, NJ: Princeton University Press.

Amenta, Edwin, Bruce Carruthers, and Yvonne Zylan. 1992. "A Hero for the Aged? The Townsend Movement, the Political Mediation Model, and the U.S. Old-Age Policy, 1934-1950." American Journal of Sociology 98 (2): 308-39.

Amenta, Edwin, and Drew Halfmann. 2000. "Wage Wars: Institutional Politics, WPA Wages, and the Struggle for U.S. Social Policy.” American Sociological Review 65 (4): 506-28.

Amenta, Edwin, Kathleen Dunleavy, and Mary Bernstein. 1994. "Stolen Thunder? Huey Long's 'Share Our Wealth,' Political Mediation, and the Second New Deal." American Sociological Review 59 (5): 678-702. 
Amenta, Edwin, and Neal Caren. 2004. "The Legislative, Organizational, and Beneficiary Consequences of State-Oriented Challengers." In The Blackwell Companion to Social Movements, edited by David A. Snow, Sarah A. Soule, and Hanspeter Kriesi, 461-88. Malden, MA: Blackwell Publishing.

Amenta, Edwin, Neal Caren, Elizabeth Chiarello, and Yang Su. 2010. "The Political Consequences of Social Movements." Annual Review of Sociology 36: 287-307.

Amenta Edwin, Neal Caren, and Sheera Joy Olasky. 2005. "Age for Leisure? Political Mediation and the Impact of the Pension Movement on U.S. Old-Age Policy." American Sociology Review 70 (3): 516-38.

Andrews, Kenneth T. 2001. "Social Movements and Policy Implementation: The Mississippi Civil Rights Movement and the War on Poverty, 1965 to 1971." American Sociological Review 66 (1): 71-95.

Andrews, Kenneth T., and Bob Edwards. 2004. "Advocacy Organizations in the U.S. Political Process." Annual Review of Sociology 30: 479-506.

Armstrong, Elizabeth A. 2002. Forging Gay Identities: Organizing Sexuality in San Francisco, 1950-1994. Chicago: University of Chicago Press.

Balboni, Jennifer M., and Jack McDevitt. 2001. "Hate Crime Reporting: Understanding Police Officer Perceptions, Departmental Protocol, and the Role of the Victim: Is There Such a Thing as a 'Love' Crime?' Justice Research and Policy 3 (1): 1-27.

Barclay, Scott, Lynn C. Jones, and Anna-Marie Marshall. 2011. "Two Spinning Wheels: Studying Law and Social Movements." Studies in Law, Politics, and Society 54: 1-16.

Beirich, Heidi. 2011. "Geographical Analysis of Hate Groups Listed by SPLC Released." May 11, 2011. https://www.splcenter.org/hatewatch/2011/05/11/geographical-analysis-hate-groups-listedsplc-released.

Bernstein, Mary. 1997. "Celebration and Suppression: The Strategic Uses of Identity by the Lesbian and Gay Movement.” American Journal of Sociology 103 (3): 531-65.

Berrill, Kevin T., and Gregory M. Herek. 1990. "Primary and Secondary Victimization in AntiGay Hate Crimes: Official Response and Public Policy.” Journal of Interpersonal Violence 5 (3): 401-13.

Berry, William D., Evan J. Ringquist, Richard C. Fording, and Russell L. Hanson. 1998. "Measuring Citizen and Government Ideology in the American States, 1960-93." American Journal of Political Science 42 (1): 327-48.

Best, Joel. 2012. Damned Lies and Statistics: Untangling Numbers from the Media, Politicians, and Activists. Berkeley: University of California Press.

Boutcher, Steven A. 2011. "Mobilizing in the Shadow of the Law: Lesbian and Gay Rights in the Aftermath of Bowers v. Hardwick." Research in Social Movements Conflict and Change 31: 175-205.

Boutcher, Steven, Anne Kronberg, and Regina Werum. 2018. "Getting on the 'Radar Screen': Homeschooling Litigation as Agenda Setting, 1972-2007." Mobilization 23 (2): 159-80.

Briones-Robinson, Rhissa, Ràchael A. Powers, and Kelly M. Socia. 2016. "Sexual Orientation Bias Crimes Examination of Reporting, Perception of Police Bias, and Differential Police Response." Criminal Justice and Behavior 43 (12): 1688-709.

Coe, Anna-Britt. 2012. "Policy Change as One Piece of the Picture: Outcomes among Reproductive Rights Advocates in Peru." Journal of Gender Studies 21 (2): 151-67.

Cress, Daniel M., and David A. Snow. 2000. "The Outcomes of Homeless Mobilization: The Influence of Organization, Disruption, Political Mediation, and Framing." American Journal of Sociology 105 (4): 1063-104.

Criminal Justice Data Brief. 2003. Department of the Attorney General: Crime Prevention and Justice Assistance Division. April 2003. http://ag.hawaii.gov/cpja/files/2013/01/Hate-Crimes2002.pdf.

Cronin, Shea W., Jack McDevitt, Amy Farrell, and James J. Nolan. 2007. "Bias-Crime Reporting: Organizational Responses to Ambiguity, Uncertainty, and Infrequency in Eight Police Departments." American Behavioral Scientist 51 (2): 213-31.

Curtis Jr., Russell L., and Louis A. Zurcher, Jr. 1973. "Stable Resources of Protest Movements: The Multi-Organizational Field." Social Forces 52 (1): 53-61.

D’Augelli, Anthony R., and Linda D. Garnets. 1995. "Lesbian, Gay, and Bisexual Communities." In Lesbian, Gay, and Bisexual Identities over the Lifespan, edited by Anthony R. D'Augelli and Charlotte J. Patterson, 293-320. New York: Oxford University Press. 
DeWitt, Brian, Anthony Glassman, and Patti Harris. 2001. "Two Plead Guilty in Camp Attack." Gay People's Chronicle, November 16, 2001. http://www.gaypeopleschronicle.com/stories/ 01 nov16.htm.

Dwyer, John P. 1990. "The Pathology of Symbolic Legislation.” Ecology Law Quarterly 17 (2): 233-316.

Eaklor, Vicki Lynn. 2008. Queer America: A GLBT History of the 20th Century. Westport, CT: Greenwood Publishing Group.

Edwards, Bob, and John D. McCarthy. 2004. "Resources and Social Movement Mobilization." In The Blackwell Companion to Social Movements, edited by David A. Snow, Sarah A. Soule, and Hanspeter Kriesi, 116-52. Malden, MA: Blackwell Publishing.

Federal Bureau of Investigation. 2019. Hate Crimes: Defining a Hate Crime. https://www.fbi.gov/ investigate/civil-rights/hate-crimes.

Felson, Marcus. 1994. Crime and Everyday Life: Insights and Implications for Society. Thousand Oaks, CA: Pine Forge.

Freeman, Jo. 1983. Social Movements of the Sixties and Seventies. New York: Longman.

Ghaziani, Amin. 2015. "Gay Enclaves Face Prospect of Being Passé: How Assimilation Affects the Spatial Expression of Sexuality in the United States." International Journal of Urban and Regional Research 39 (4): 756-71.

Gibson, Christopher L. 2017. "The Consequences of Movement Office-Holding for Health Policy Implementation and Social Development in Urban Brazil." Social Forces 6 (2): 751-78.

Gladfelter, Andrew S., Brendan Lantz, and R. Barry Rubak. 2017. "The Complexity of Hate Crime and Bias Activity: Variation across Contexts and Types of Bias." Justice Quarterly 34 (1): $55-83$.

Goldberg, Suzanne B. 2015. "Obergefell at the Intersection of Civil Rights and Social Movements." California Law Review Circuit 6: 157-65.

Goldstone, Jack A. 2004. "More Social Movements or Fewer? Beyond Political Opportunity Structures to Relational Fields." Theory and Society 33: 333-65.

Gorman-Murray, Andrew, and Catherine J. Nash. 2016. "LGBT Communities, Identities and the Politics of Mobility: Moving from Visibility to Recognition in Contemporary Urban Landscapes." In The Routledge Research Companion to Geographies of Sex and Sexualities, edited by Gavin Brown and Kath Browne, 247-53. New York: Routledge.

Grattet, Ryken. 2009. "The Urban Ecology of Bias Crime: A Study of Disorganized and Defended Neighborhoods." Social Problems 56 (1): 132-50.

Grattet, Ryken, and Valerie Jenness. 2008. "Transforming Symbolic Law into Organizational Action: Hate Crime Policy and Law Enforcement Practice." Social Forces 87 (1): 501-27.

Grattet, Ryken, Valerie Jenness, and Theodore R. Curry. 1998. "The Homogenization and Differentiation of Hate Crime Law in the United States, 1978 to 1995: Innovation and Diffusion in the Criminalization of Bigotry." American Sociological Review 63 (2): 286-307.

Green, Donald P., Dara Z. Strolovitch, and Janelle S. Wong. 1998. "Defended Neighborhoods, Integration, and Racially Motivated Crime." American Journal of Sociology 104 (2): 372-403.

Haider-Markel, Donald P. 1998. "The Politics of Social Regulatory Policy: State and Federal Hate Crime Policy and Implementation Effort." Political Research Quarterly 51 (1): 69-88.

---. 2002. "Regulating Hate: State and Local Influences on Hate Crime Law Enforcement." State Politics and Policy Quarterly 2 (2): 126-60.

Haider-Markel, Donald P., and Kenneth J. Meier. 1996. "The Politics of Gay and Lesbian Rights: Expanding the Scope of the Conflict." Journal of Politics 58 (2): 332-49.

Herek, Gregory M. 1989. "Hate Crimes against Lesbians and Gay Men." American Psychologist 44 (6): 948-55.

---. 2017. "Documenting Hate Crimes in the United States: Some Considerations on Data Sources." Psychology of Sexual Orientation and Gender Diversity 4 (2): 143-51.

Herek, Gregory M., and Kevin Berrill, eds. 1992. Hate Crimes: Confronting Violence against Lesbians and Gay Men. Newbury Park, CA: Sage Publications.

Herek, Gregory M., Jeanine C. Cogan, and J. Roy Gillis. 2002. "Victim Experiences in Hate Crimes Based on Sexual Orientation." Journal of Social Issues 58: 319-39.

Holder, Eaven. 2018. "Political Competition and Predictors of Hate Crime: A County-Level Analysis." MA thesis, East Tennessee State University.

Human Rights Campaign. 2008. Pennsylvania Hate Crimes Law. http://www.hrc.org/resources/ entry/state-laws-policies. 
Jenkins, J. Craig. 1983. "Resource Mobilization Theory and the Study of Social Movements." Annual Review of Sociology 9: 527-53.

Jenness, Valerie. 1999. "Managing Differences and Making Legislation: Social Movements and the Racialization, Sexualization, and Gendering of Federal Hate Crime Law in the US, 1985-1998.” Social Problems 46 (4): 548-71.

Jenness, Valerie, and Ryken Grattet. 1996. "The Criminalization of Hate: A Comparison of Structural and Polity Influences on the Passage of 'Bias-Crime' Legislation in the United States." Sociological Perspectives 39 (1): 129-54.

---. 2001. Making Hate a Crime: From Social Movement to Law Enforcement. New York: Russell Sage Foundation.

Johnson, Erik W. 2008. "Social Movement Size, Organizational Diversity and the Making of Federal Law." Social Forces 86 (3): 967-93.

Kane, Melinda D. 2003. "Social Movement Policy Success: Decriminalizing State Sodomy Laws, 1969-1998." Mobilization 8 (3): 313-34.

---. 2007. "Timing Matters: Shifts in the Causal Determinants of Sodomy Law Decriminalization, 1961-1998." Social Problems 54 (2): 211-39.

---. 2010. "You've Won, Now What? The Influence of Legal Change on Gay and Lesbian Mobilization, 1974-1999." Sociological Quarterly 51 (2): 255-77.

King, Ryan D. 2007. "The Context of Minority Group Threat: Race, Institutions, and Complying with Hate Crime Law." Law and Society Review 41 (1): 189-224.

King, Ryan D., Steven F. Messner, and Robert D. Baller. 2009. "Contemporary Hate Crimes, Law Enforcement, and the Legacy of Racial Violence." American Sociological Review 74 (2): 291-315.

Lazar, Aryeh, and Joseph H. Hammer. 2018. "Religiousness and Anti-Gay/Lesbian Attitudes: The Mediating Function of Intratextual Religious Fundamentalism.” Psychology of Violence 8 (6): 763-771.

Levy, Brian L., and Denise L. Levy. 2017. "When Love Meets Hate: The Relationship between State Policies on Gay and Lesbian Rights and Hate Crime Incidence." Social Science Research 61: $142-59$.

Loftus, Jeni. 2001. "America's Liberalization in Attitudes toward Homosexuality, 1973 to 1998." American Sociological Review 66 (5): 762-82.

Long, J. Scott. 1997. Regression Models for Categorical and Limited Dependent Variables. Thousand Oaks, CA: Sage Publications.

Lyons, Christopher J. 2008. "Defending Turf: Racial Demographics and Hate Crime Against Blacks and Whites." Social Forces 87 (1): 357-85.

Masucci, Madeline, and Lynn Langton. 2017. Hate Crime Victimization, 2004-2015, Bureau of Justice Statistics. https://www.bjs.gov/content/pub/pdf/hcv0415.pdf.

McAdam, Doug. 1982. Political Process and the Development of Black Insurgency, 1930-1970. Chicago: University of Chicago Press.

McCammon, Holly J., Karen E. Campbell, Ellen M. Granbeg, and Christine Mowery. 2001. "How Movements Win: Gendered Opportunity Structures and U.S. Women's Suffrage Movements, 1866-1919." American Sociological Review 66 (1): 49-70.

McCarthy, John D., and Mayer N. Zald. 1977. "Resource Mobilization and Social Movements: A Partial Theory." American Journal of Sociology 82 (6): 1212-41.

McMahon, Brian T., Steven L. West, Allen N. Lewis, Amy J. Armstrong, and Joseph P. Conway. 2004. "Hate Crimes and Disability in America." Rehabilitation Counseling Bulletin 47 (2): 66-75.

McVeigh, Rory, Carl Neblett, and Sarah Shafiq. 2006. "Explaining Social Movement Outcomes: Multiorganizational Fields and Hate Crime Reporting." Mobilization: An International Journal 11 (1): 23-49.

McVeigh, Rory, Michael R. Welch, and Thoroddur Bjarnason. 2003. "Hate Crime Reporting as a Successful Social Movement Outcome." American Sociological Review 68 (6): 843-67.

Meyer, Doug. 2008. "Interpreting and Experiencing Anti-Queer Violence: Race, Class, and Gender Differences among LGBT Hate Crime Victims." Race, Gender \& Class 15 (3-4): 262-82.

--- 2012. "An Intersectional Analysis of Lesbian, Gay, Bisexual, and Transgender (LGBT) People's Evaluations of Anti-Queer Violence." Gender \& Society 26 (6): 849-73.

Minkoff, Debora C. 1997. "National Social Movements and Civil Society." American Behavioral Scientist 40 (5): 606-19. 
Nolan, James J., and Yoshio Akiyama. 1999. "An Analysis of Factors that Affect Law Enforcement Participation in Hate Crime Reporting." Journal of Contemporary Criminal Justice 15 (1): $111-27$.

Nolan, James J., Yoshio Akiyama, and Samuel Berhanu. 2002. "The Hate Crime Statistics Act of 1990: Developing a Method for Measuring the Occurrence of Hate Violence." American Behavioral Scientist 46 (1): 136-53.

Olkin, Ingram, Jean Dickinson Gibbons, and Milton Sobel. 1999. Selecting and Ordering Populations: A New Statistical Methodology. New York: John Wiley \& Sons.

Olzak Susan, and Sarah A. Soule. 2009. "Cross-Cutting Influences of Environmental Protest and Legislation.” Social Forces 88 (1): 201-25.

Parris, Christie L., and Heather L. Scheuerman. 2015. "How Social Movements Matter: Including Sexual Orientation in State-Level Hate Crime Legislation." Research in Social Movements, Conflicts and Change 38: 231-57.

PFLAG. 2016. "PFLAG Works in Coalition with DOJ on Trans Best Practices Law Enforcement Video." August 25, 2016. https://www.pflag.org/blog/pflag-works-coalition-doj-trans-bestpractices-law-enforcement-video.

Rayside, David. 1998. On the Fringe: Gays and Lesbians in Politics. Ithaca, NY: Cornell University Press.

Riggs, Jamie D., and Trent L. Lalonde. 2017. Handbook for Applied Modeling: Non-Gaussian and Correlated Data. New York: Cambridge University Press.

Sampson, Robert J., and W. Byron Groves. 1989. "Community Structure and Crime: Testing Social Disorganization Theory." American Journal of Sociology 94 (4): 774-802.

Sampson, Robert J., Stephen W. Raudenbush, and Felton Earls. 1997. "Neighborhoods and Violent Crime: A Multilevel Study of Collective Efficacy." Science 227 (5328): 918-24.

Shaw, Clifford, and Henry McKay. 1942. Juvenile Delinquency and Urban Areas. Chicago: University of Chicago Press.

Shorter, Edward, and Charles Tilly. 1974. Strikes in France, 1830-1968. London: Cambridge University Press.

Smith, Kevin B. 1997. "Explaining Variation in State-Level Homicide Rates: Does Crime Policy Pay?" Journal of Politics 59 (2): 350-67.

Smith, Miriam Catherine. 2008. Political Institutions and Lesbian and Gay Rights in the United States and Canada. New York: Routledge.

Soule, Sarah A. 2004. "Going to the Chapel? Same-Sex Marriage Bans in the United States, 1973-2000.” Social Problems 51 (4): 453-77.

Soule, Sarah A., and Susan Olzak. 2004. "When Do Movements Matter? The Politics of Contingency and the Equal Rights Amendment." American Sociological Review 69 (4): 473-97.

Staggenborg, Suzanne. 1991. The Pro-Choice Movement: Organization and Activism in the Abortion Conflict. New York: Oxford University Press.

STATA. 2015. How Can I Use Countfit in Choosing a Count Model? https://stats.idre.ucla.edu/ stata/faq/how-can-i-use-countfit-in-choosing-a-count-model/.

Stotzer, Rebecca L. 2010a. "Seeking Solace in West Hollywood: Sexual Orientation-Based Hate Crimes in Los Angeles County." Journal of Homosexuality 57 (8): 987-1003.

---. 2010b. "Sexual Orientation-Based Hate Crimes on Campus: The Impact of Policy on Reporting Rates." Sexuality Research and Social Policy 7 (3): 147-54.

Sturdy, Steve, Jennifer Smith-Merry, and Richard Freeman. 2012. "Stakeholder Consultation as Social Mobilization: Framing Scottish Mental Health Policy." Social Policy \& Administration 46 (7): 823-44.

Tarrow, Sidney. 1998. Power in Movement: Social Movements and Contentious Politics. Cambridge, UK: Cambridge University Press.

Tilly, Charles. 1978. From Mobilization to Revolution. Reading, MA: Addison-Wesley.

Torres-Reyna, Oscar. 2007. Panel Data Analysis: Fixed and Random Effects Using STATA. http:// www.princeton.edu/ otorres/Panel101.pdf.

Uniform Crime Reports. 2015. Hate Crimes: Victims. https://ucr.fbi.gov/hate-crime/2015/topicpages/victims_final.

US Census Bureau. 2008. The Statistical Abstract of the United States, 2008: Elections. Washington, DC: US Government Printing Office. https://www.census.gov/library/publications/ 2007/compendia/statab/127ed/elections.html.

US Equal Employment Opportunity Commission. 2018. Facts about Discrimination in Federal Government Employment Based on Marital Status, Political Affiliation, Status as a 
Parent, Sexual Orientation, and Gender Identity. https://www.eeoc.gov/federal/ otherprotections.cfm.

Weatherburn, Don. 2001. "What Causes Crime?" Crime and Justice Bulletin: Contemporary Issues in Crime and Justice 54 (February): 1. https://www.bocsar.nsw.gov.au/Documents/CJB/ cjb54.pdf.

Werum, Regina, and Bill Winders. 2001. "Who's 'In' and Who's 'Out': State Fragmentation and the Struggle over Gay Rights, 1974-1999.” Social Problems 48 (3): 386-410.

Williams, Richard. 2015. Interpreting Interaction Effects; Interaction Effects and Centering. https:// www3.nd.edu/ rwilliam/stats2/153.pdf. 